\title{
Analysis of Second Primary Lung Cancers Developed Following Different System Tumors
}

\section{Farklı Sistem Tümörlerini Takiben Gelişen İkinci Primer Akciğer Kanserlerinin Analizi}

\author{
Çiğdem Özdilekcan ${ }^{1}$, Sevim Turanlı ${ }^{2}$ Necla Songür ${ }^{3}$, Hüseyin Çakmak ${ }^{4}$ \\ ${ }^{1}$ Dr. A. Y. Ankara Oncology Training And Research Hospital, Department Of Chest Disease, Ankara, Turkey \\ ${ }^{2}$ Dr. A. Y. Ankara Oncology Training And Research Hospital, Depatment Of General Surgery, Ankara, Turkey \\ ${ }^{3}$ Istanbul Sisli Memorial Hospital Department Of Chest Disease Istanbul \\ ${ }^{4}$ Dr. A. Y. Ankara Oncology Training And Research Hospital, Department Of Chest Surgery, Ankara, Turkey
}

\section{ÖZET}

Amaç: Bu çalışmada farklı sistem malignitelerine sekonder olarak gelişen akciğer tümörlerin klinik özellikleri ve primer tümörle olan ilişkilerinin araştırılması amaçlandı.

Yöntemler: 2002-2010 yılları arasında takipleri sırasında ikinci primer kanser tanısı alan otuz hasta çalışmaya dahil edildi. Hastalar, akciğer kanseri gelişme sürelerine göre senkron (n: 7 hasta, \%16.7) ve metakron (n: 23 hasta, \%83.3) grup olarak iki grupta değerlendirildi.

Bulgular: Hastaların \%50'sinde ilk 2.5 yıl içinde ikinci primer kanser saptandı. Hastaların çoğunluğunun (\%43.3) akrabalarında ekstra pulmoner kanser öyküsü vardı. Akciğer kanseri tanısı konulan hastalardan \%50'sinde sigarayı bırakma, \%30'unda aktif içici ve \%20'sinde hiç sigara kullanmamış olma öyküsü vardı. Primer kanser ile ilgili yapılan tedaviye yanıt ve ikincil gelişen kanserin süresi arasında istatistiksel olarak anlamlı bir ilişki saptanmadı $(\mathrm{p}=0.36)$. Grupların tamamında sağ kalım süresi 24 ay senkron grupta, 12 ay metakron grupta belirlendi.

Sonuç: Primer hastalıktan sonra özellikle ilk 2.5 yıl içinde yakın takip ve hastalara sigara içiciliğinin bıraktırılmasının teşvik edilmesi önem taşımaktadır.

Anahtar Kelimeler: Akciğer kanseri; ikinci primer; senkron; metakron

\begin{abstract}
Objective: This study aimed to investigate clinical characteristics and prognosis of secondarily developed lung tumors in the cases having different system malignancy and to evaluate the relationship with the primary tumor. Methods: Between January 2002- December 2010 thirty patients diagnosed as second primary lung cancer have been included in the study. The patients were grouped according to lung cancer development time; synchronous group (n: 7 patients, 16.7\%) and metachronous group (n: 23 patients, 83.3\%).

Results: Second cancer was detected in $50 \%$ of the patients within the first 2.5 years. Majority of patients had extra pulmonary cancer history concerning their relatives $(43.3 \%)$. The rate of quitting smoking among all patients before the diagnosis of lung cancer was 50\%, current smoker rate was $30 \%$ and never smoker was $20 \%$. There was no statistical relationship between the response to treatment of first cancer and the duration of cancer developed secondarily ( $\mathrm{p}=0.36$ ). The overall survival of groups was found 24 months $(95 \%$ confidence interval: 18.3 months) and 12 months (95\% confidence interval: 10-14 months) respectively for synchronous and metachronous groups.

Conclusion: Close follow-up on pulmonary system especially within the first 2.5 years after primary disease and encouragement on quitting smoking is important.
\end{abstract}

Key words: Lung carcinoma, second primary; synchronous; metachronous

\section{Introduction}

Multiple primary malignancies (MPM) are defined as malignant neoplasm those occur apart from the first cancer. Observations of
MPM were previously considered as isolated and exceptional cases. However, as a result of the improvement in diagnostic tools, treatment modalities and supportive care, survival time for cancer patients has been prolonged and the 
number of MPM has continued to grow (1). Since the number of patients with MPM continues to grow, clinicians should be aware of this danger and try to detect the second primary cases as early as possible. The rate of development second primary cancer was reported as $1.7-3.9 \%$ (1-3). The causative factor for this unwanted result can be due to long survival of patients, immune deficiency, genetic defects, and /or a hereditary defect in tumor suppressor genes, advanced age, dietary factors, treatment modalities, occupational factors, and current smoking (1,2). During the last decade an increase in the incidence of MPM has been reported (4).

The aim of the present study was to evaluate clinical characteristics and prognosis of secondarily developed lung tumors in the cases having different system malignancy and to examine the relationship with the primary tumor.

\section{Methods}

\section{Study population}

Between January 2002- December 2010, 30 patients diagnosed as second primary lung cancer those admitted to Dr. A. Y. Ankara Oncology Training and Research Hospital during follow up and staging for their primary tumor have been included in the study. In this retrospective study, cases were selected among the ones who have been suspected of lung cancer according to their symptoms, radiological and clinical findings. Confirmation of histopathological diagnosis was the main point of ultimate patient selection. Besides Warren and Gates criteria i) each of the tumors must present a definite picture of malignancy; each must be distinct, ii) second primary tumor should be lung cancer, iii) there should be histological documentation of each malignant lesion, iv) the cases with the existence of metastatic lesion of the lungs or metastatic lesions from the lungs must be excluded from the study, v) lesions occurring greater than 6 months apart are defined as metachronous and those occurring within 6 months are defined as synchronous] was taken into consideration to define second primary malignancies $(1,5)$. The patients were grouped according to lung metastasis development time; group I, synchronous group ( $\mathrm{n}=7$ patients) and group II, metachronous group ( $\mathrm{n}=23$ patients). The data were collected retrospectively and approved by our instutional ethical committee.

The patients' data was included patients characteristics (age, gender, occupation, family cancer history, smoking habit, duration of quitting smoking), primary tumor characteristics (date of diagnosis, the localization of primary tumor, histopathology, stage, treatment methods and the response to treatment) and the findings associated second primary lung cancer (date of diagnosis, pulmonary symptoms, radiological findings, bronchoscopic findings, diagnostic procedure, histopathological findings). The treatment response criteria have been adapted from the original response evaluation criteria in solid tumors (RECIST) (6).

\section{Statistical analysis}

Descriptive statistic was used for the distribution of patient demographic characteristics and tumor-related characteristics, diagnosis and systemic treatment. Overall survival (OS) was defined as the length of time between diagnosis of second primary lung cancer to death or last follow-up. Kaplan-Meier curves for OS was estimated by the development time of lung carcinoma, and compared using the log rank test. These analyses were used to calculate the relative risk and $95 \%$ confidence intervals (CI). $\mathrm{P}$ values <.05 were considered as statistically significant. All analyses were carried out using SPSS software (version 13.0; SPSS Inc, Chicago, IL).

\section{Results}

The distribution of synchronous and metachronous tumors was $16.7 \%$ and $83.3 \%$ respectively. Of the thirty patients with lung cancer, 26 were male and four were female. The age of primary malignancy and second primary lung malignancy was median 59.5 (range, 38-82 years) and 63 years (range, 3983 years $)$ respectively $(\mathrm{p}=0.10)$. In synchronous tumors the duration of time between two malignancies was median one month (range, 1-5 months) while it was median 36 months (9-168 months) in the metachronous ones, overall 31 months (range, 1-168 months). 
The rate of quitting smoking among all patients before the diagnosis of lung cancer was $50 \%$, current smoker rate was $30 \%$ and never smoker was $20 \%$. Majority of patients had extra pulmonary cancer history concerning their relatives $(43.3 \%)$. The localization of primary cancers is shown in Table 1 . The most frequent primary localization was larynx (40\%) and the most frequent histopatological diagnosis was squamous cell carcinoma (SCC).

Table 1. The localization of primary cancer

\begin{tabular}{|lcc|}
\hline \hline Localization & Patients No & $\mathbf{( \% )}$ \\
\hline \hline Larynx & & \\
Prostate & 12 & $40 \%$ \\
Bladder & 4 & $13.3 \%$ \\
Skin & 2 & $6.7 \%$ \\
Bowel & 1 & $3.3 \%$ \\
Breast & 3 & $10.0 \%$ \\
Stomach & 2 & $6.7 \%$ \\
Soft tissue & 2 & $6.7 \%$ \\
sarcoma & 1 & $3.3 \%$ \\
Testis & & \\
Cervix & 1 & $3.3 \%$ \\
Brain & 1 & $3.3 \%$ \\
\hline
\end{tabular}

Second primary lung cancer was detected in $50 \%$ of the patients within the first 2.5 years. The feature of patients and tumor characteristics of second primary lung cancer are given Table 2 . The most frequent symptom of the patients was cough and hemoptisis, while 20\% were asymptomatic. During the diagnosis different biopsy methods were used to confirm the lung cancer (bronchoscopic biopsy in 19 patients, transthoracic needle aspiration biopsy in 6 patients, surgical biopsy in 3 patients and pleural biopsy in 2 patients). Mostly bronchial biopsies $(100 \%$ in synchronous group and $52.1 \%$ in metachronous group) were diagnostic tools in patients. Staging of second primary lung cancer revealed mostly stage III-IV disease.

Treatment modalities for the primary localized tumor and second primary lung cancer are given Table 3. Majority of patients received surgical treatment for primary localized carcinoma, while for secondarily developed carcinoma, the most frequent treatment choice was chemotherapy and/or best supportive care. This can be attributed as an advanced stage for lung cancer patients. The lung tumor was removed by surgically in 4 patients with second primary lung cancer (one patient in synchronous group and 3 patients in metachronous group).

When treatment response was taken into account for the primary localized tumor; complete response rate was $80 \%$, and partial response rate was $20 \%$. There was no statistical relationship between the response to treatment of first cancer and the duration of cancer developed secondarily $(\mathrm{p}=0.36)$. When the data collection was completed in December 2009 , the patients had a median follow-up of 12 months (range, 1-84 months) after the diagnosis of lung carcinoma. The patients who had synchronous and metachronousous lung carcinoma were compared for OS, the survey graphic is given in Figure 1. The OS of groups was found 24 months (95\% CI: $18-30$ months) and 12 months (95\% CI: 10-14 months) respectively $(\mathrm{p}=0.65)$. At the end of the study period, 4 patients $(57.1 \%)$ in group I and 3 patients in group II (13.0\%) were still alive.

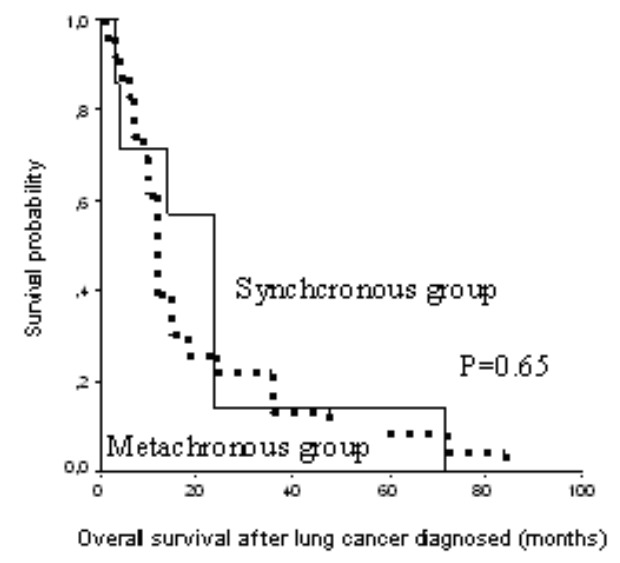

Figure 1. The curve showing overall survival of metachronous and synchronous tumor groups (Kaplan-Meier).

\section{Discussion}

There are relatively few population-based data regarding development of second primary carcinoma of lung following different system tumors. However our previous knowledge showed that 3 various type of lung cancer can develop; 1) lung cancer after lung cancer 2) lung cancer after different system cancer 3 ) different system cancer after lung cancer (4). 
Following different system carcinomas especially upper aerodigestive tract, rectal, anal, cervix and thyroid gland, bladder, and Hodgkin lymphoma second lung cancers were observed $(7,8)$. The risk of a second primary malignancy in patients who have had a SCC of the head and neck is significantly increased compared with the age-matched general population (9). Two large contemporary cancer registry studies provide insights into the magnitude and details of the increased risk. The most frequent second malignancy was lung cancer (20-year cumulative risk 13\%) $(10,11)$. Radiation therapy can increase the risk

Table 2. The features of patients and tumor characteristics of second primary lung cancer

\begin{tabular}{|c|c|c|c|c|}
\hline & & $\begin{array}{ll}\text { All } & \text { Patients } \\
(\mathrm{n}: 30) & \end{array}$ & $\begin{array}{l}\text { Synchronous } \\
\text { group (n:7) }\end{array}$ & $\begin{array}{l}\text { Metachronous } \\
\text { group (n:23) }\end{array}$ \\
\hline \multicolumn{2}{|l|}{ Age (median years) } & 63 & 62 & 63 \\
\hline \multicolumn{2}{|l|}{$\operatorname{Sex}(\mathrm{M} / \mathrm{F})^{*}$} & $26 / 4$ & $7 / 0$ & $19 / 4$ \\
\hline \multicolumn{2}{|l|}{ Family history for cancer } & $13(43.3 \%)$ & $3(42 \%)$ & $10(43.4 \%)$ \\
\hline \multirow{3}{*}{ Smoking status } & Current smoker & \multirow{3}{*}{$\begin{array}{l}9(30 \%) \\
15(50 \%) \\
6(20 \%)\end{array}$} & \multirow{3}{*}{$\begin{array}{l}3(42 \%) \\
4(57 \%) \\
0\end{array}$} & \multirow{3}{*}{$\begin{array}{l}6(26 \%) \\
11(47.8 \%) \\
6(26 \%)\end{array}$} \\
\hline & Ex smoker & & & \\
\hline & Never smoker & & & \\
\hline \multirow{2}{*}{$\begin{array}{l}\text { Respiratory } \\
\text { Symptoms }\end{array}$} & Symptomatic & $24(80 \%)$ & $3(42 \%)$ & $21(91.3 \%)$ \\
\hline & Asymptomatic & $6(20 \%)$ & $4(57 \%)$ & $2(8.6 \%)$ \\
\hline \multirow[t]{2}{*}{ Location of tumor } & Peripheral & $12(40 \%)$ & $1(14.2 \%)$ & $11(47.8 \%)$ \\
\hline & Central & $18(60 \%)$ & $6(85.8 \%)$ & $12(52.2 \%)$ \\
\hline \multirow[t]{2}{*}{ Histopathology } & Nonsmall cell & $27(90 \%)$ & $7(100 \%)$ & $20(86.9 \%)$ \\
\hline & Small cell & $3(10 \%)$ & 0 & $3(13.04 \%)$ \\
\hline \multirow{4}{*}{ Stage NSCLC** (TNM) } & I & 0 & 0 & 0 \\
\hline & II & $2(6.6 \%)$ & $1(14.3 \%)$ & $1(4.4 \%)$ \\
\hline & III & $13(43.4 \%)$ & $5(71.4 \%)$ & $8(34.8 \%)$ \\
\hline & IV & $12(40 \%)$ & $1(14.3 \%)$ & $11(47.8 \%)$ \\
\hline \multirow[t]{2}{*}{ Stage SCLC*** } & Limited Disease & $2(6.6 \%)$ & 0 & $2(8.7 \%)$ \\
\hline & Extensive Disease & $1(3.4 \%)$ & 0 & $1(4.3 \%)$ \\
\hline
\end{tabular}

$* * *$ Male /Female **NSCLC: Nonsmall cell lung cancer $* * *$ SCLC:Small cell lung cancer

Table 3. Treatment modalities for the primary localized tumor and second primary lung cancer

\begin{tabular}{|l|l|l|}
\hline \hline Treatment & $\begin{array}{l}\text { Primary cancer } \\
\text { Patients no }(\%)\end{array}$ & $\begin{array}{l}\text { Second primary lung cancer } \\
\text { Patients no }(\%)\end{array}$ \\
\hline \hline Surgery & $13(43.3)$ & $4(13.3)$ \\
\hline CT & $1(3.3)$ & $9(30)$ \\
\hline RT & $2(6.7)$ & $3(10)$ \\
\hline Surgery +RT & $9(30)$ & - \\
\hline Surgery+ CT & $2(6.7)$ & - \\
\hline Surgery+CT+RT & $3(10)$ & - \\
\hline CT+RT & - & $6(20)$ \\
\hline Cranial RT alone & - & $2(6.7)$ \\
\hline Best supportive care & - & $6(20)$ \\
\hline
\end{tabular}

CT: Chemotherapy

of a second primary lung cancer in patients who have been treated for other malignancies. This increased risk has been demonstrated in patients with both Hodgkin lymphoma and breast cancer $(12,13)$. In the British National Lymphoma Investigation, for example, one-
RT: Radiotherapy

third of all excess malignancies were lung cancers (14). The risk of developing or dying from a second malignancy is two to three times greater in survivors of testicular cancer than in the general population. The largest study to date included 40,576 testicular cancer 
survivors from 14 population-based tumor registries in Europe and North America; more than 7800 were followed for 20 years, and 2065 were followed for 30 years (15). Cancer of the lung, colon, bladder, pancreas, and stomach accounted for almost $60 \%$ of the total excess number of solid tumors. Individuals with esophageal adenocarcinomas are at a higher risk of developing second cancers of the stomach, oropharynx and lung/bronchus (16). In our study the majority of cases were larynx carcinoma and the other localization are given in Table 1.

Patients treated for head and neck carcinoma frequently develop second primary tumors in the lung (17). The risk of second primary lung cancer in this group of patients is 14-47\%. Differing hypotheses exist regarding this propensity of the upper aeorodigestive tract for developing second cancers. Slaughter et al. has proposed the concept of "condemned mucosa" developing after chronic carcinogen exposure leading to field cancerisation of the aero digestive tract (18). Carey et al. has countered that field cancerisation may be monoclonal with second tumors developing from micrometastatic tumor deposits breaking off from the original primary tumor and growing in other subsides of the tract (19).

We especially observed tobacco related cancers mostly. All of the larynx carcinoma cases in our study had history of smoking; therefore we think that smoking behavior as a chronic carcinogen exposure can result with second lung carcinomas via unique airway tract. Although quitting of smoking was advised for each patient after the first cancer diagnosis, we observed that $30 \%$ of patients continued to smoke in whole study group. Especially $42 \%$ of synchronous group was current smoker during the diagnosis of second cancer. It has been reported in a meta-analysis of Parsons et al. smoking cessation after diagnosis of cancer would prevent larger number of estimated number of deaths expected from cardiovascular deaths as well as mortality gained due to cancer progression (20). Close follow-up on pulmonary system especially within the first 2.5 years after primary disease and encouragement on quitting smoking becomes important. Family history of cancer was present $43.3 \%$ of all study cases (42\% and $43.4 \%$ respectively for synchronous and metachronous group) that indicates majority of cases had cancer history in their first-degree relatives. Thus MPM need to be investigated for genetic susceptibility. From the Swedish Family Cancer - Database, Xinjun $\mathrm{Li}$ et al. declared that lung cancer has been one of the main cancer types for studies on the effects of genetic polymorphisms (5). It has also been documented that association of cervix carcinoma and lung cancer may be due to be infected by human papilloma virus (HPV) which is also a carcinogenic factor for lung cancer (21). This relationship should be supported by further studies.

Histopathological appearance was nearly similar when we observed lung and larynx cases. Mostly SCC in both cases was observed. Thus the differential diagnosis of both tumors is frequently difficult. In this study all of our cases were selected among those mainly overlapping with clinical and histopatological criteria of Warren and Gates as previously mentioned. Suspected of cases with metastasis were absolutely excluded from the study.

Majority of our patients received surgical treatment for primary localized carcinoma, while for secondarily developed carcinoma, the most frequent treatment choice was chemotherapy. Because of advanced stages only 4 patients $(13.4 \%)$ were surgery candidates. Therefore, chemotherapy was the first choice for this group. Unfortunately, we should here emphasize a delay in the diagnosis of second cancer, since the stages were advanced at the time of diagnosis. This result can be attributed to both delay of patients or physicians. Lack of pulmonary symptoms, delay of routine control for the first cancer, underestimation of radiological scanning may be the reasons for this circumstance. Scanning with chest computerized tomography is essential since this method can detect smaller lesions earlier than a chest radiograph (22). The OS of synchronous groups was found median 24 months and median 12 months for metachronous group $(\mathrm{p}=0.65)$. This result indicated poor prognosis due to second cancer. Patients in whom a distant metastasis or second primary lung cancer develops are more likely to die of second cancer than of the initial tumor, distinguishing primary tumors from metastatic diseases is therefore essential. Since, curative treatment alternatives are considered in existence of primary lung tumors 
while systematic treatments and limited surgery approaches are used in metastatic cases. Metachronous and synchronous tumors are also needed to be differentiated when second primary tumor develops. The treatment modalities are to be distinct, treatment priorities should be defined especially in synchronous groups.

The limitations of our study were relatively small number of patients which restricted the statistical power. Because of this reason survival was calculated independent of disease stage and histopatological results. Definitely, these two factors are the most important parameters of a OS. Therefore, we here want to emphasize that large number of series with subgroup analysis can be the ideal approach.

Distinguishing primary tumors from metastatic diseases is essential since, curative treatment alternatives are considered in existence of primary lung tumors while systematic treatments and limited surgery approaches are used in metastatic cases. Close follow-up on pulmonary system especially within the first 2.5 years after primary disease and encouragement on quitting smoking is important after the diagnosis of primary cancer.

Acknowledgement: The authors would like to thank Dr. Ilknur Bostanci for her excellent support in every step of the preparation of this paper.

\section{Conflict of Interest: None}

\section{References}

1. Liu YY, Chen YM, Yen SH, Tsai CM, Perng RP. Multiple primary malignancies involving lung cancer-clinical characteristics and prognosis. Lung Cancer 2002;35:189-94

2. Watanabe S, Kodama T, Shimosato Y, et al. Multiple primary cancers in 5,456 autopsy cases in the National Cancer Center of Japan. J Natl Cancer Inst 1984;72:1021-7

3. Curtis RE, Boice JD Jr, Kleinerman RA, Flannery JT, Fraumeni JF Jr. Multiple primary cancers in Connecticut and Denmark. NCI Monogr 1985;68:219-42

4. Levi F, Randimbison L, Te VC, La Vecchia C. Second primary cancers in patients with lung carcinoma. Cancer 1999;86:186-90

5. Holland JM, Arsanjani A, Liem BJ, Hoffelt SC, Cohen JI, Stevens KR Jr. Second malignancies in early stage laryngeal carcinoma patients treated with radiotherapy. Journal of Laryngology \& Otology 2002;1163:190-3

6. Eisenhauer EA, Therasse P, Bogaerts J, et al. New response evaluation criteria in solid tumors: revised RECIST guideline (version 1.1). Eur J Cancer 2009;45:228-47

7. Hsu YB, Chang SY, Lan MC, Huang JL, Tai SK, Chu PY. Second primary malignancies in squamous cell carcinomas of the tongue and larynx: an analysis of incidence, pattern, and outcome. J Chin Med Assoc 2008;71:86-91

8. Behrens C, Travis LB, Wistuba II, et al. Molecular changes in second primary lung and breast cancers after therapy for Hodgkin's Disease. Cancer Epidemiology, Biomarkers and Prevention 2000;9:1027-35

9. Atienza JA, Dasanu CA. Incidence of second primary malignancies in patients with treated head and neck cancer: a comprehensive review of literature. Curr Med Res Opin 2012;28:1899-909

10. Chuang SC, Scelo G, Tonita JM, et al. Risk of second primary cancer among patients with head and neck cancers: A pooled analysis of 13 cancer registries. Int J Cancer 2008; 123:2390

11. Morris LG, Sikora AG, Patel SG, Hayes RB, Ganly I. Second primary cancers after an index head and neck cancer: subsite-specific trends in the era of human papillomavirus-associated oropharyngeal cancer. J Clin Oncol 2011;29:739

12. Lorigan P, Radford J, Howell A, Thatcher N. Lung cancer after treatment for Hodgkin's lymphoma: a systematic review. Lancet Oncol 2005;6:773

13. Kaufman EL, Jacobson JS, Hershman DL, Desai M, Neugut AI. Effect of breast cancer radiotherapy and cigarette smoking on risk of second primary lung cancer. Journal of Clinical Oncology 2008;26:392-8

14. Swerdlow AJ, Douglas AJ, Hudson GV, Hudson BV, Bennett MH, MacLennan KA. Risk of second primary cancers after Hodgkin's disease by type of treatment: analysis of 2846 patients in the British National Lymphoma Investigation. BMJ 1992;304:1137

15. Travis LB, Fosså SD, Schonfeld SJ, et al. Second cancers among 40,576 testicular cancer patients: focus on long-term survivors. J Natl Cancer Inst 2005;97:1354

16. Nandy N, Dasanu CA. Incidence of second primary malignancies in patients with esophageal cancer: a comprehensive review. Curr Med Res Opin 2013;29:1055-65

17. Geurts TW, Nederlof PM, van den Brekel MW, et al. Pulmonary squamous cell carcinoma following head and neck squamous cell carcinoma: Metastasis or second primary? Clin Cancer Research 2005;11:6608-14

18. Slaughter DP, Southwick HW, Smejkal W. Field cancerization in oral stratified squamous epithelium. Cancer 1953;6:963-8

19. Carey T. Field cancerization: are multiple primaries monoclonal or polyclonal? Ann Med 1996;28:183-8

20. Parsons A, Daley A, Begh R, Aveyard P. Influence of smoking cessation after diagnosis of early stage lung cancer on prognosis: systematic review of observational studies with meta- analysis. BMJ 2010;340:b5569 
21. Li X, Hemminki K. Familial and second lung cancers: a nation- wide epidemiologic study from Sweden. Lung Cancer 2003;39:255-63

22. Tan L, Greener CC, Seikaly H, Rassekh CH, Calhoun $\mathrm{KH}$. Role of screening chest computed tomography in patients with advanced head and neck cancer. Otolaryngology - Head and Neck Surgery 1999;120:689-92 